Rev. Biol. Trop., 48(2/3): 591-604, 2000

www.ucr.ac.cr www.ots.ac.cr www.ots.duke.edu

\title{
New species in the New World Natada complex (Lepidoptera: Limacodidae)
}

\author{
Jorge F. Corrales ${ }^{1}$ and Marc E. Epstein ${ }^{2}$ \\ 1 Instituto Nacional de Biodiversidad (INBio), 22-3100, Sto. Domingo, Heredia, Costa Rica. \\ Fax (506)2440690, jcorral@inbio.ac.cr \\ 2 Department of Entomology, Smithsonian Institution, Washington, D.C. 20560, USA.
}

Received 18-VIII-1999. Corrected 5-XI- 1999. Accepted 1-XII- 1999.

\begin{abstract}
The following new species in the New World Natada complex are described: Natada minuscula, Natada cecilia, Natada lalogamezi, Natada kokii, Natada monteverdensis, Narosopsis iangauldi, and Euprosterna wemilleri. Natada minuscula is the smallest known species in the complex. Of the new species, only Natada kokii, Natada cecilia and Narosopsis iangauldi are known to occur outside of Costa Rica. Previously the New World Natada complex had 43 species in the neotropics. It is anticipated that the proportion of new species in the complex will exceed other major lineages of Limacodidae found in Costa Rica.
\end{abstract}

Key words: Limacodidae, Natada complex, Natada, Narosopsis, Euprosterna, Costa Rica.

Natada Walker is presently one of few pantropical limacodid genera, with type species $N$. rufescens Walker (by subsequent designation) found in Asia. In addition to Natada, members in the New World complex include Euprosterna Dyar, Isa Packard, Narosopsis Dyar, and Platyprosterna Dyar (Epstein, 1996). These genera are in need of revision, with the last complete treatment of the taxa by Dyar (1935). Epstein and Becker (1993) did preliminary work on the complex, finding new synonymies and creating new combinations. The spiny larvae found in the New World Natada complex can be separated from those of the Parasa complex by the absence of deciduous spine patches at the base of the A8 and A9 dorsal scoli and the absence of a saddleback pattern. Both of these characteristics, however, can be absent in the Parasa complex as well (see also Dyar 1899a). Larvae vary in their overall shape and in the length of scoli in the Natada complex. Late instars are sometimes round in cross section and have small, equally sized dorsal and subdorsal scoli (e.g., Natada nasoni Grote; Dyar, 1899b). Others are flattened with dorsal scoli reduced in size and subdorsal scoli elongated (e.g., Is a textula (Herrich-Schaeffer), Dyar, 1896; Euprosterna elaea (Druce), Genty et al. 1978). Larvae in the Phobetron complex are superficially similar to the flat type; however, they have an elongated dorsal row and a reduced subdorsal row (Dyar, 1899a). Adults in the Natada complex usually have antennae bipectinate to the apex in males and are always filiform in females. The forewing commonly has a pair of lines, one arising at the median of the anal margin and the other near the tornus, which meet or are proximate on the subapex of the costal margin to form a triangle or trapezoid with the anal margin. Forewing $R_{3}$ and $R_{4}$ are stalked off of $R_{2}$ or between $R_{2}$ and $R_{5}$. The haustellum (= proboscis) is usually reduced or absent, and labial palps often appear truncate at the apex because the small apical segment is 
reflexed, relative to the long penultimate segment, and is often obscured by scales. The tibial spurs are 0-2-4 (e.g., Natada) or are 0-2-2 in some of the species in smaller genera. Similar New World species in the Perola complex can be distinguished from the Natada complex by having stalked forewing cubital veins and female antennae that are bipectinate or serrate. In this paper we add seven new species to the New World Natada complex, which previously had 43 species in the neotropics (Becker and Epstein, 1995). As we prepare "A Guide to Costa Rican Limacodidae," it is anticipated that the proportion of new species in the Natada complex will exceed other major lineages of Limacodidae found in Costa Rica.

\section{SPECIMENS STUDIED}

Specimens examined in this study are from the following collections: Instituto Nacional de Biodiversidad (INBio); National Museum of Natural History, Smithsonian Institution (USNM); Natural History Museum of Los Angeles Co. (LACM); Vitor O. Becker private collection, Brasilia, Brazil (VOB); The Natural History Museum, London (BMNH); American Museum of Natural History, New York (AMNH); Museum of Comparative Zoology, Harvard University (MCZ). Paratypes or additional voucher material not found in the USNM and INBio collections will be deposited at each institution following the completion of the guide book. INBio bar codes (CRI\#\#\#) under "Material Examined" are for data base purposes only and do not indicate the collection of deposition. Geographic coordinates (Lambert system) are indicated by LN or LS numbers associated with the bar codes.

\section{Natada minuscula sp. $\mathbf{n}$}

(Figs. 1, 2, 22)

Adult male (Fig. 22). Forewing length 5-7 $\mathrm{mm}$. Head, collar and dorsal thorax lighter brown. Wings, body and legs dark brown. Forewing $R_{3}$ and $R_{4}$ stalked off $R_{5}$ near junc- tion of $R_{2}$. Labial palps at least $21 / 4 \mathrm{X}$ eye length and directed frontally with light brown scales; third segment evident, bent at approx. $45^{\circ}$ relative to longer second segment. Scales on mid- and hind tibia light brown, lighter than dark brown forelegs, and femora and tarsi of other legs. Tibial spurs long and of subequal length; 0-2-4. Antenna bipectinate to apex. Haustellum absent.

Female. Unknown.

Male genitalia (Figs. 1, 2). Uncus with distal $1 / 3$ slightly angled downward, with tiny curved claw at apex. Gnathos extending almost as far as uncus, nearly horizontal. Inner surface of valva with a pair of processes from a common base, arising proximal to medial portion of sacculus; a medial androconial scale patch above base of processes extends over much of valva except margins. Juxta a simple sclerotized horizontal plate below aedeagus. Aedeagus slightly curved at base below; distal part slightly constricted before apex and upturned at nearly a right angle, with a rounded margin. Saccus triangulate to posterior.

Remarks: The genitalia of $N$. minuscula are similar to those found in Natada caria (Druce) and Isa brusha (Dyar). N. minuscula differs from other "microlimacodids" (e.g., Microphobetron Dyar) in the presence of bipectinate versus laminate antenna and the presence of subequal tibial spurs (spurs are unequal in length in Microphobetron). The name minuscula refers to the small size of this species, the smallest known in the Natada complex.

Distribution: Known only from Costa Rica.

Material Examined (4 specimens $O^{\prime \prime}$ )

Holotype O Costa Rica: LIMON: Hacienda Tapezco, 29 air km W Tortuguero, el. $40 \mathrm{~m}$ lat. $10^{\circ} 30^{\prime} \mathrm{N}$, long. $83^{\circ} 47^{\prime} \mathrm{W}, 13$ March 1978, JP Donahue, D. Panny, D. Moeller, C. Lewis, (LACM)(CRI001145701).

Paratypes. Costa Rica: LIMON: Hacienda Tapezco, 29 air km W Tortuguero, el. 40m lat.

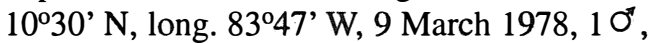
J. P. Donahue, D. Panny, D. Moeller, C. Lewis, (LACM) (CRI001120799), 13-31 Aug.1979, 1 O', J.P. \& K.E. Donahue, C.C. Hair, N.K. 

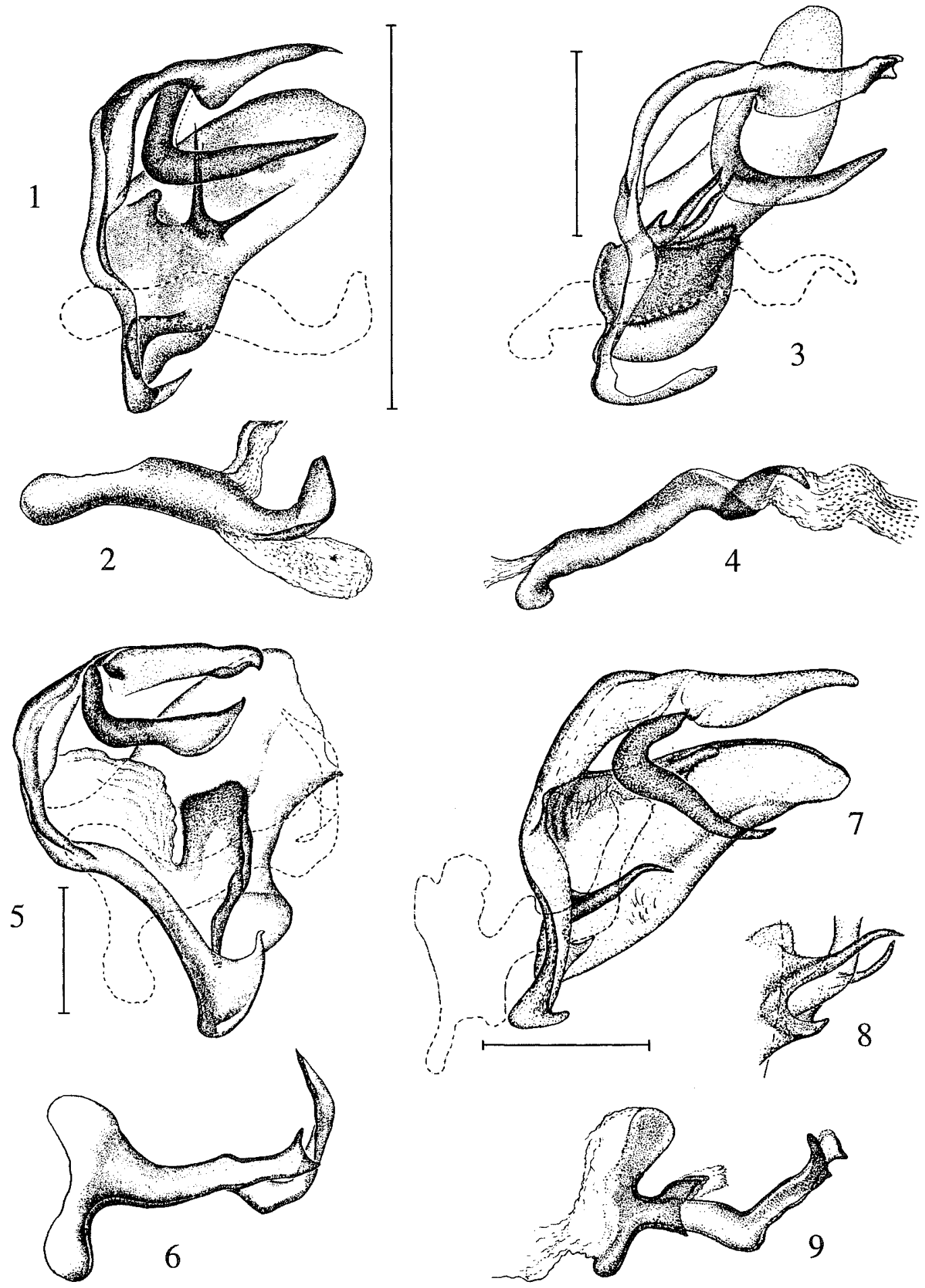

Figures 1-9. Male genitalia (lateral views vith left valva removed). 1-2, Natada minuscula, new species: 1, lateral view of genitalia; 2, aedeagus; (INBIOCRI01145701); 3-4, Natada cecilia, new speces: 3, lateral view; 4, aedeagus (INBIOCRI00619960); 5-6, Natada monteverdensis, new species: 5, lateral view; 6, aedeagus (INBIOCRI 01357878); 7-9. Natada lalogamenzi 7, lateral view; 8, detail of lateral view of juxta; 9, aedeagus (INBIOCRI101319618). (scale=1 mm). 
Moore, M.A. Hopkins, (LACM)(genitalia prep. MEE 117)(CRI001121341); HEREDIA: Est. Biol, La Selva, 50-150m, 10²6' N, 8401' W 16-28-iv 1996, 1 O', D.Wagner (CRI001121329).

\section{Natada cecilia $\mathbf{s p .} \mathbf{n}$.}

(Figs. 3, 4, 18, 19, 23, 24)

Adult male (Fig. 23). Forewing length 10 $10.5 \mathrm{~mm}$. Ground color of wings and body dark brown. Forewings brown with a curved black line, convex to outer margin, beginning near distal end of $1 \mathrm{~A}+2 \mathrm{~A}$, extending over connection of $R_{2}$ to stalk of $R_{3}$ and $R_{4}$, ending at costal margin $2 / 3$ from base; small black spot on vein $M_{1}$ at end of discal cell. Marginal areas beyond black line are light reddish brown in contrast to dark brown submedial and medial areas; basal and postmedial region bordering dark line may grade to light brown or as dark as medial area. Hindwings dark brown with same tones as medial areas of forewings. Labial palps long, at least $2 \mathrm{X}$ length of eye and directed upwards; second segment brown with a black spot in front, third segment short without truncate appearance typical in Natada. Brown legs with cream scales at end of each tarsus; tibial spurs $0-2-4$. Antenna short, less than $1 / 2$ length of forewing. Haustellum present.

Adult female (Fig. 24). Forewing length 13$14 \mathrm{~mm}$. Forewing $R_{3}$ and $R_{4}$ stalked off of $R_{5}$. Similar to male in both coloration and patterns, although slightly lighter hue. Haustellum absent.

Male genitalia (Figs. 3, 4). Uncus claw anterior to apex, dorsum slightly raised in apical 1/4. Gnathos upcurved, not extending as far as uncus. Valva narrow, directed dorsad with cucullus above uncus; sacculus sinuate, with inward bend 1/3 distance from base. Transtilla with a median rounded portion and two smooth, sclerotized arms projecting upward and two smaller lateral lobes below. Juxta with paired lobes, membranous and hairy. Aedeagus with short basal portion obliquely connected to longer distal portion, sclerotized apex coiled (like a corkscrew); vesica with spinules. Saccus a median lobe projecting to posterior.
Female genitalia (Figs. 18, 19). Ductus bursae narrow in distal $1 / 3$ between antrum and connection to ductus seminalis, and $3 \mathrm{X}$ initial width beyond; corpus bursae ovoid, approx. equal in length to ductus bursae. Ostium bursae wide, with antrum sclerotized, bowl shaped and covered with short setae. Ventral margin of papillae anales horizontal, at right angles to lateral margins. Anterior apophyses short, approximately a quarter length of posterior apophyses, curved dorsad; posterior apophyses reaching proximal to anterodorsal margin of 8 th segment. Lateral lobes of 8th segment (="lateral lugs" of Holloway; 1986) longer than anterior apophyses. Posterodorsal part of 8th segment with paired digitate lobes projecting laterad.

Remarks: Possibly related to Natada ceres (Druce) from Mexico, which has similar male genitalia. $N$. ceres also has a haustellum, although only in females. $N$. cecilia is unusual both in the New World Natada complex and in limacodids for having a haustellum present in the male and absent in the female. Male genitalia (aedeagus and uncus), and female posterodorsal digitate lobes are similar to those Natada incandescens Dyar. The first author has dedicated the species name to Cecilia Mayorga, nature lover, friend and mother.

Distribution: Panama, Costa Rica, Honduras and Mexico.

Material Examined (11 specimens, $30^{\prime \prime}, 8$ )

Holotype O". Costa Rica: PUNTARENAS: Est. Sirena, P. N. Corcovado, 1-100 m, G. Fonseca, Abr 1994, (LS 270500508300)(CRI001797987).

Paratypes. Mexico: Campeche, Escarcega 85 m, 1 O", 17-21 Jun 1981, (VOB); Honduras: Tegucigalpa, 1 O", 7 Sept. 1973, (VOB); Costa Rica: GUANACASTE: Est. Pitilla, $9 \mathrm{~km} \mathrm{~S}$. Santa Cecilia, 700 m, (LN 330200-380200), 2 $\%$, GNP Biodiversity Survey, May 1988, Sep 1988, (CRI001055624, CRI001055625), 1 \%, C. Moraga, 19 May-3 Jun 1993, (CRI001341688), 2 9 , P. Rios, Oct 1994, Nov 1994, (CRI002122708, CRI002110052); HEREDIA: Est. Magsasay, P. N. Braulio Carrillo, 200 m, (LN 264600-531100), 1 O", A. 

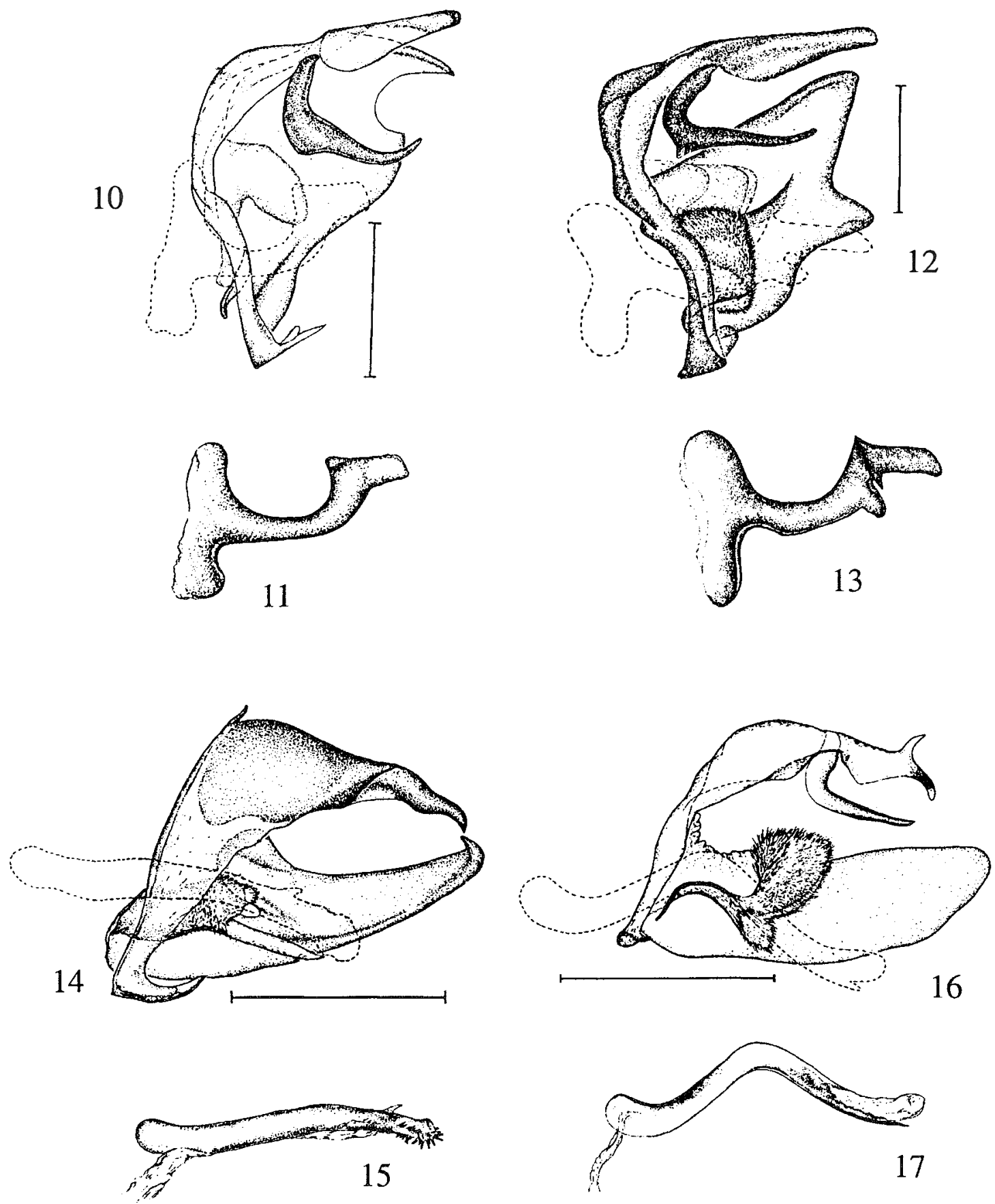

Figures 10-17. Male genitalia (lateral views with left valva removed). 10-13, Natada kokii, new species: 10, lateral view of genitalia; 11, aedeagus (INBIOCRI00245397); 12, lateral view of genitalia; 13, aedeagus (INBIOCRI01120984); 14-15, Narosopsis iangauldi, new species: 14, lateral view of genitalia; 15, aedeagus (INBIOCRI00226344); 16-17. Euprosterna wemilleri: 16, lateral view of genitalia; 17, aedeagus (INBIOCRI01118857). (scale=1 mm). 
Fernandez, Nov 1990, (CRI000246169); PUNTARENAS: Est. Sirena, P. N. Corcovado, 0-100 m, (LS 270500-508300), 1 ه", G. Fonseca, Feb 1992, (CRI000619960); Panama: Barro Colorado, CZ, 1 \& , 21 Mar 1933, (AMNH).

\section{Natada monteverdensis sp. $\mathbf{n}$.}

(Figs. 5, 6, 25)

Adult male (Fig. 25). Forewing length 15 $\mathrm{mm}$. Ground color of wings and body light brown. Forewing with scattered dark scales and two lines, medial and submarginal, typical of Natada, though faint; medial line intersects a faint spot at end of discal cell; submarginal line slightly concave to outer margin; stalk of $R_{3}$ and $R_{4}$ connects at junction of $R_{2}$ and $R_{5}$. White scale patch on scape of antenna and front coxa. Scattered orange scales on dorsum of thorax and abdomen, not extending to vertex. Labial palps at least $2 \mathrm{X}$ length of eye and directed forward, appearing wider and truncate at apex. Tibial spurs 0-2-4. Antennae bipectinate and long, approx. $2 / 3$ forewing length. Haustellum absent.

\section{Adult female. Unknown.}

Male genitalia (Figs. 5, 6). Uncus without a pronounced claw at apex; distal quarter slightly produced below. Gnathos shorter than uncus, sinuate below, laterally compressed, with narrow apex upcurved. Valva upcurved from base to distal $1 / 3$ above and below, with small round process on costa near distal end; inner surface with dense patch of fixed setae in depression approx. 1/3 from sacculus to costa, narrowing to about $1 / 2$ at cucullus; no androconial scales in evidence. Transtilla consists of a pair of membranous sacks. Juxta more sclerotized below, broadly connected to anellus, which is covered by spinules above. Aedeagus with basal portion at right angle to and shorter than distal portion; dorsal hump approx. equal in length to basal portion, truncate above; a long process, around length of distal arm, arises on apical 1/3 of distal arm from below and curved upward and transverse (right to left) to a single point; apex of aedeagus with two short points, one an upward spine and another a transverse lobe. Saccus triangulate and pointed cephalad.
Remarks: This large high elevation species is closest to Natada nindla Dyar of species known to occur in Costa Rica.

Distribution: Known only from Costa Rica. All specimens were collected in Monteverde Cloud Forest at approximately 1500 m elevation.

Material examined (11 specimens $\left.\sigma^{\prime \prime}\right)$

Holotype O", Costa Rica: PUNTARENAS: Buen Amigo, San Luis Monteverde, 1000-1350 m, Z. Fuentes, SET 1994, (LN 250850-449250)(CRI002022185).

Paratypes. Costa Rica: PUNTARENAS: Buen Amigo, San Luis Monteverde, 1000$1350 \mathrm{~m}, 1 \mathrm{O}$, Z. Fuentes, SET · 1994, (LN 250850-449250)(CRI002022211); Est. La Casona, Res. Biol. Monteverde, 1520 m, 2 O", N. Obando, Ago 1991, (CRI001357878, CRI001357909); Monte Verde, 1 O , Janzen \& Hallwachs, 20-21 July 1982, (CRI001120985); Monte Verde, 1 đ", Charles V. Covell Jr, 4000 ft, 7 Aug. 1986, (USNM)(CRI001121284); Monte Verde, 1400 m (LACM): 1 O", C. Nagano \& M. Hayes, 1-20 Sept. 1982, (LACM) (CRI001121333); 4. O", Eric M. Fisher, 11-18 Aug. 1976, Mercury Vapor, (LACM)(CRI001121334， CRI001121335, CRI001121336, CRI001121337).

\section{Natada lalogamezi sp. $\mathbf{n}$.}

(Figs. 7, 8, 9, 26)

Adult male (Fig. 26). Forewing length 10.7-13.8 mm. Forewings dark brown with two lines typical of Natada; lines are more evident in damaged or faded specimens. Small black spot at base of vein $\mathrm{M}_{1}$ on medial line. Hindwings brown with dark brown scales dispersed over ventral part. Dorsal thorax and abdomen dark brown with brick red band, widening near anterior part of thorax to form a collar. Head with brown front and brick red scales toward labial palps. Labial palps at least $2 X$ length of eye and directed forward. Hindlegs dark brown with a patch of white scales at distal end of femora, tibia and tarsi; mid- and hindlegs dark brown; tibial spurs 0-24. Antennae bipectinate to apex, approx. 1/2 forewing length. Haustellum absent. 

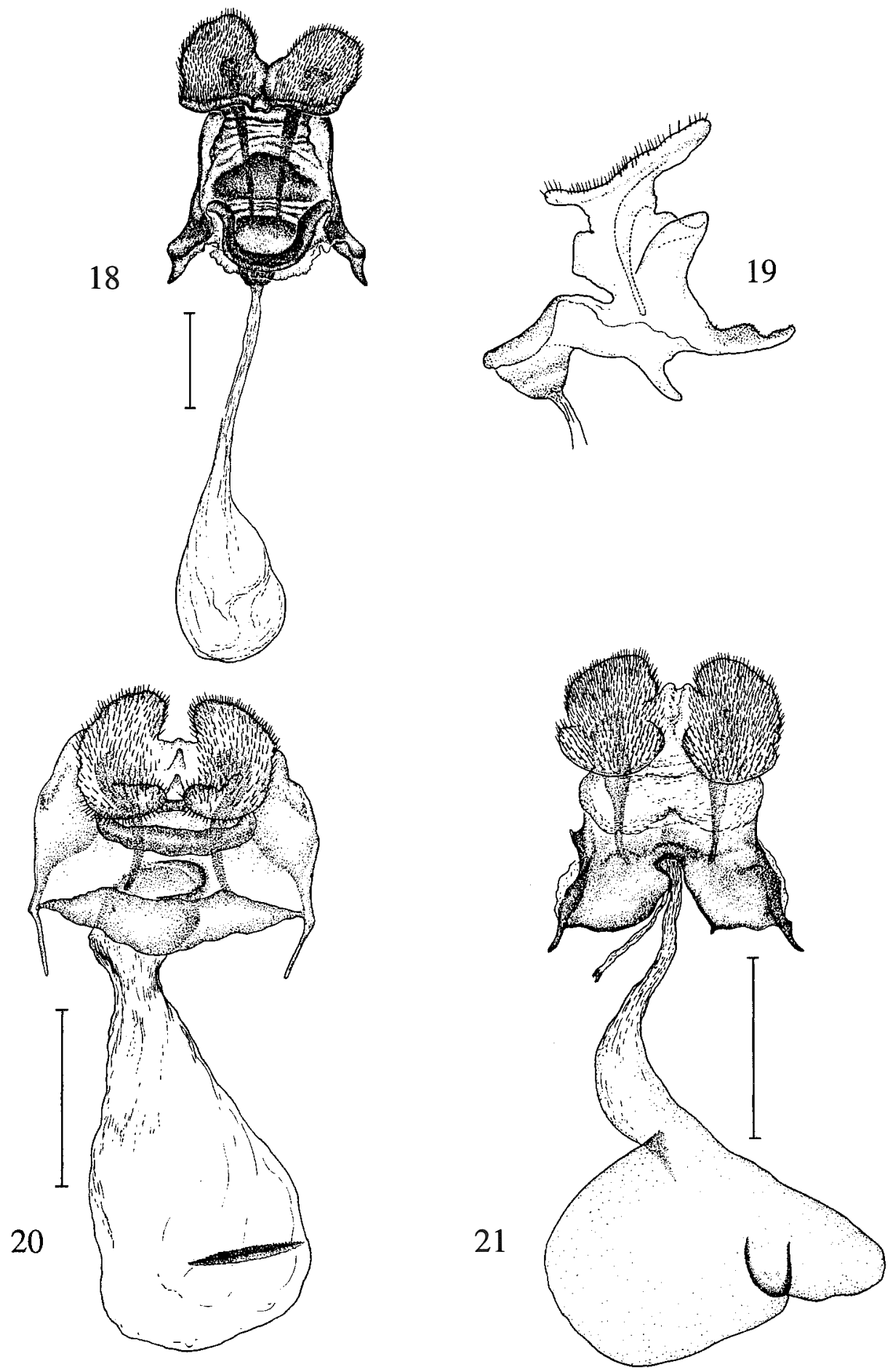

Figures 18-21. Female genitalia (ventral view). 18, Natada cecilia, new species; 19, lateral view (INBIOCRI000055624); 20, Natada iangauldi, (INBIOCRI000086022); 21, Euprosterna wemilleri $($ INBIOCRI002139099) $(\mathrm{scale}=1 \mathrm{~mm})$. 
Adult female. Unknown

Male genitalia (Figs. 7, 8, 9). Uncus tip flat without spine, slightly curved from lateral margin to median. Gnathos sinuate, narrow in distal 1/3 and upcurved at apex, shorter than uncus. Valva somewhat triangulate, angled and horizontal along costa with incurved process midway from base, while sinuate below and curved near apex. Transtilla with membranous sacks extending to medial portion of valvae (corresponding to depressed area on inner surface of valva). Juxta with pair of curved processes laterad of aedeagus; small sclerotized process dorsad of aedeagus on short anellus. Aedeagus base shorter than distal arm with large dorsal process constricted at base and longer than basal portion; one distal spine upcurved from right to left contacting gnathos.

Remarks: Natada lalogamezi, based on male genitalia, appears to be closely related to Natada incandescens, which lacks a band on the forewing. Other Neotropical species with forewing bands are more similar in external appearance to $N$. lalogamezi (e.g., $N$. miradora Dyar and $N$. pucara (Dognin)). This species is named for the noteworthy educator, Eulalislao Gámez, for his arduous dedication and meaningful contributions to democratizing education in Costa Rica.

Distribution: Known only from Costa Rica. Material Examined (12 specimens $O^{\prime \prime}$ )

Holotype $\sigma^{\prime}$. Costa Rica: GUANACASTE: Est. Pitilla, 700 m, 4-22 agosto 1993, Calixto Moraga (CRI001118507).

Paratypes. Costa Rica: GUANACASTE: Est. Cacao, 1000-1400 m, Lado SO Vol. Cacao, P. N. Guan. Prov. Guanacaste, 1 O', May 1992, D. H. Janzen, W. Hallwachs (LN 323300-375700)(CRI000851937); LIMON: Cerro Tortuguero, P. N. Tortuguero. 100 m, 1 O' April 1989, R. Aguilar \& J. Solano (LN 285000-588000) (CRI000018318); Rio Sardinas, 10 m, R. N. F. S. Barra del Colorado, 2 O", 2 julio 1992, F. Araya (LN 291500-564700) (CRI000696606, CRI000696572); Sector Cerro Cocori, Fca. de Elias Rojas, 1 O', Abr 1991, E. Rojas (LN 286000-567500) (CRI001111621); Turrialba, 600 m, 1 O’, 25
Oct 1972, V.O. Becker, (VOB); PUNTARENAS: Parque Nacional Manuel Antonio, Quepos, 80 m, 1 Ơ, May 1991, R. Zuñiga (LS 370900-448800) (CRI001319618), 1 ơ, Oct 1993, G. Varela (LS 370900-448800) (CRI001998624); Buenos Aires, PILA, Sector Altamira., A. C. Amistad, 1150-1400 m, 1 O’, May 1994, R. Delgado (LS 572100-331700) (CRI001860281); La Selva Biol. Sta., Puerto Viejo de Sarapiqui, 40 m, 1 O’, 11 Jan 1986, M. M. Chavarria, A. Chacon, W. Hallwachs, D. Janzen (CRI001119979), La Selva Biol. Sta., Puerto Viejo de Sarapiqui, 40 m, 1 O', 28 Nov8 Dec 1986, M. M. Chavarria (CRI001120986).

\section{Natada kokii sp. n.}

(Figs. 10, 11, 12, 13, 27)

Adult male (Fig. 27). Forewing length 9.2$15 \mathrm{~mm}$. Ground color of wings and body dark brown. Forewings èspecially dark within triangle formed from submarginal and medial lines typical of Natada, and in submarginal area beyond it. Submarginal line has reddish brown scales extending from costa, gradually widening to vein $\mathrm{CuAl}$ to form a band $4 \mathrm{X}$ wider than at its origin (in worn specimens part near tornus forms a distinctive reddish area). Cream colored scales concentrated near each vein along outer margin of submarginal line from costa through $\mathrm{CuA} 1$, more pronounced near costa, sometimes forming a line in between. Small patch of black scales found between veins $M_{1}$ and $M_{2}$ at end of discal cell. Labial palps at least $2 \mathrm{X}$ eye length and pointed forward. Forelegs dark brown with patch of white scales on front of coxae and trochanter and cream colored at extreme distal ends of femora, tibia and tarsi. Mid- and hindlegs dark brown with tarsal scales as in forelegs; tibial spurs 0-2-4. Antenna bipectinate to apex; with cream colored scape. Haustellum absent.

Adult female. Unknown

Male genitalia (Figs. 10, 11, 12, 13). Uncus somewhat flattened, gradually tapering to truncate tip without claw. Gnathos narrow and sinuate below, upcurved in distal $1 / 3$, not reaching beyond middle of uncus. Valva with thinner setose medial portion reaching distal end, 
forming concave margin; costa upcurved reaching above gnathos; sacculus narrowed in middle. Transtilla paired membranous sacks. Juxta mostly membranous with small basal plate between valvae. Aedeagus with long dorsal projection from smaller basal portion and distal portion upcurved, with capitate apex reaching approx. same height as dorsal projection. Saccus with small triangulate portion directed to posterior between valvae and a second narrow plate below, also directed to posterior.

Remarks: Natada kokii can be easily confused with Isa diana (Druce). Male N. kokii have a submarginal band and a discal spot not found in male I. diana. Specimens of female $I$. diana have a faint submarginal band, but no discal spot. N. kokii may also have forms that occur above $1000 \mathrm{~m}$. Four larger male specimens from higher elevations, one from Cerro de la Muerte (forewing length $13 \mathrm{~mm}$ ), two from La Reserva Tapanti (forewing length 14 $\mathrm{mm}$ ) and the other from Volcan Irazu (forewing length $15 \mathrm{~mm}$ ), each have similar but distinct genitalia from Natada kokii and relatively long, straight antennae. Examination of additional specimens from highlands are needed to determine if they are distinct species or high altitude forms. The specimen from Cerro de la Muerte is unique in the presence of a densely setose anellus and an aedeagus with the apex angled downward (Figure 12-13); the wings of the specimen are greasy, making it difficult to determine its coloration or pattern. The specimen from Irazu has the same coloring as $N$. kokii except it lacks white scales on the front femora, and has an uncus apex that is broader relative to the basal portion and upturned; the apex of the aedeagus is missing. We have encountered similar genitalic variations between what appear to be isolated montane and lowland populations in other Costa Rican limacodid species (e.g., Miresa clarissa (Stoll) and Euclea spp.). This species is named in honor of Bernardo "Koki" Espinoza for his outstanding efforts and dedication to his work.

Distribution: Known from Costa Rica and Panama.
Material examined: (29 specimens $\left.\sigma^{\prime \prime}\right)$

Holotype O". Costa Rica: PUNTARENAS: Sirena, Corcovado N. P., 0-100 m. G. Fonseca, Nov 1989 (LS 270500-508300) (CRI000114151).

Paratypes. Costa Rica: GUANACASTE: Barra Honda, m, (LN 239000-386000), 1 O', M. Reyes, Nov 1994 (CRI001996875); Guanacaste Conserv. Area, 1 O", D. H. Janzen Voucher Specimen Database 92.SRNP.4582 (CRI001148946); PUNTARENAS: Sirena, Corcovado N. P. 0-100 m., (LS 270500508300), 4 O', G. Fonseca, Nov 1989 (CRI000113795, CRI0001 13675, CRI000113790, CRI000114151), 2 O゙, G. Fonseca, Oct 1991, (CRI000347979, CRI000347982), 1 O゙, G. Fonseca, Oct 1989, (CRI00278565); 1 O", C. Saborio, Oct 1990, (CRI000245397); 3 O", F. Quesada, DH Janzen \& W. Hallwachs, 1 May 1984, 10-19 Aug 1980, 1 May 1984, (CRI001120802, CRI001120800, CRI001 120801); Est. Q. Bonita, R. B. Carara, $50 \mathrm{~m}$, (LN 194500-469850), 3 O゙, R Guzmán, 10 a 28 ago 1992, (CRI000866215), Set 1993 (CRI001660547), Dic 1993, (CRI001655721), 3 O', J. C. Saborio, May 1993 (CRI001 198762), nov 1993, (CRI001969937), Dic 1994 (CRI002113347), 1 O", Ene 1993, (CRI001359727); P. N. Manuel Antonio, $80 \mathrm{~m}$, Quepos, (LS 370900-448800), 2 O', G. Varela, Ago 1991 (CRI001317579), Nov 1991, (CRI000403994); $1.8 \mathrm{mi} \mathrm{W}$ of Rincon, Osa Peninsula, 1 Ơ, JF Donahue, CL Hogue,19 February 1971, (CRI001120804); Panama: Barro Colorado Isl., 1 O", 25-28 Mar. 1965, S.S. \& W.D. Duckworth, (USNM), (CRI001121339).

Other material. Costa Rica: CARTAGO: La Represa Tapantí, 1800 m, (LN 185900-563300), 1 Ơ, R. Delgado, Jul 1995, (CRI001149976); R. Grande de Orosi, desde el puente R. Dos Amigos hasta la Represa, 1800 m, (LN 186600562000), 1 O', R. Delgado, FEB 1995, (CRI002243362); SAN JOSE: San Gerardo de Dota, Cerro de la Muerte, 1 O゙, DH Janzen \& W. Hallwachs, 23 Aug 1981, (CRI001120984); CARTAGO: Orosi, Vulkan Irazu, 1 O", coll. Fassl.Tepinz (BMNH), (CB: CRI001121340). 


\section{Narosopsis iangauldi n. sp.}

(Figs. 14, 15, 20, 28, 29)

Adult male (Fig. 28). Forewing length 7.5$9 \mathrm{~mm}$. Body cream to brownish yellow. Forewings brownish yellow with a clearly visible light brown band between tornus and subapex on costa; dark brown scales dispersed over entire wing surface, forming three prominent small black spots: one midway from discal cell to margin on $M_{1}$, with others on $M_{1}$ at end of discal cell and on $\mathrm{R}$ at base of wing; small spots on dorsum are repeated on ventrum (in good specimens or dark form). Forewing $R_{3}$ and $R_{4}$ stalked off of $R_{2}$. Specimens range from very yellow and others more brown, sometimes having a striped appearance from brown tones and golden reflection of scales. Hindwings light yellow with a small dark brown patch between conjunction of vein $\mathrm{M}_{1}$ and $\mathrm{M}_{2}$; ventrum with dark brown patch in same location, with other brown scales dispersed over surface. Labial palps approx. $2 \mathrm{X}$ eye length, yellow with scattered dark brown scales. Legs with yellow scales; tibial spurs 0 2-2. Antenna narrowly bipectinate and curved. Haustellum absent.

Adult female (Fig. 29). Forewing length 9$11 \mathrm{~mm}$. Similar to male in pattern and coloration. Antenna filiform. Haustellum absent.

Male genitalia (Figs. 14, 15). Uncus short and very narrow compared to tegumen, apex slightly downcurved. Gnathos absent. Valva triangulate, with costa horizontal at base and curved dorsomedially in narrow apical 1/3; inner margin with rounded lobe directed to anterior. Juxta with single medial process below aedeagus; annelus above aedeagus covered with spinules. Aedeagus straight; vesica with cornuti. Saccus directed to posterior, triangulate.

Female genitalia (Fig. 20). Ductus bursae broad, approx. 1/2 width and equal length to corpus bursae; corpus bursae with long transverse signum, about width of ductus bursae. Ductus seminalis connects to antrum. Ostium bursae and antrum sclerotized; lobe posterior to ostium bursae transverse, extending to margins of papillae anellus. Each lobe of papillae anales semicircular, with ventral margin more trans- verse than dorsal. Lateral lobes absent on 8th segment. Dorsum of sclerotized 8th segment positioned under 7th segment. Anterior apophyses short, curved inward; posterior apophyses extending beyond margin of 8th segment.

Remarks: Narosopsis iangauldi shares putative synapomorphies with the type species of the genus, Narosopsis leucospila Dyar. These include features of the male genitalia and the black spot on the ventrum of the hindwing. Although placed in Narosopsis, N. iangauldi is perhaps most closely related to Euprosterna notula (Dognin) from Peru. Both the type of $E$. notula and $N$. iangauldi lack a gnathos, have a short and narrow upturned uncus, numerous cornuti and have a round process on the costa of the valva that is attached distally, and a patch of coremata on the posterior end of the dorsum on A7. N. iangauldi differs from $E$. notula in the presence of a juxtal process below the aedeagus and absence of a curved process on the end of the aedeagus. Both Narosopsis leucopsila and $N$. iangauldi occur in Costa Rica, separated by the whiter color and gnathos found in N. leucospila. Although the female of $N$. leucospila is unknown, we were able to associate female $N$. iangauldi with the males by locality. Forbes's (1942) report of N. leucopsila from Barro Colorado Island (BCI), Panama appears to be incorrect. All BCI specimens we examined are $N$. iangauldi, including one determined by Forbes as $N$. leucospila in the MCZ collection.This species is named for Ian D. Gauld, whose early and unflagging enthusiasm for the development of Costa Rica's biodiversity has been a stimulus and inspiration for multitudes of Costa Rican and international biodiversity managers.

Distribution: Known from Costa Rica and Panama.

Material examined (34 specimens, $290^{\prime \prime}, 5$ \%)

Holotype O", Costa Rica: LIMON: Sector Cedrales de la Rita, 10 m, AGO 1995, E. Rojas, (LN 278600-566500) (CRI002351853).

Paratypes. Costa Rica: ALAJUELA: Sector Colonia Palmareña, $700 \mathrm{~m}$, (LN 
245900-475900), 2 O゙, J. C. Saborio, SET 1995, (CRI002341020, CRI002341025; CARTAGO: Quebrada Segunda, P. N. Tapantí, 1250 m, (LN 194000-560000), 2 o", G. Mora, Ago 1991, Abr 1993, (CRI000704833, CRI001293405); GUANACASTE: Est. Pitilla, 9 km S. Sta Cecilia, 700 m, P. N. Guanacaste (LN 330200-380200), 2 ○", C. Moraga, Jun 1991, 22 oct a 2 nov 1992, (CRI000616879, CRI000936386), 3 O", P. Ríos, 18 abril a 19 may 1993, 19 may a 3 jun 1993, Oct 1994, (CRI001397896, CRI001354230, CRI002122734), 1 \& , FEB 1995, (CRI002135402; HEREDIA: Est. Magsasay, P. N. Braulio Carrillo, $200 \mathrm{~m}$, (LN 264600-531100), 1 ○", M. Zumbado, Oct 1990, (CRI000180626; LIMON: Turrialba, 1 o", 1-6 III [Mar] [19]65, S.S. \& W.D. Duckworth, (USNM), (CRI001120807); Turrialba, 600m, 1 O', 25 VIII [Aug] 1971, 1 ₹ , 8 IV [Apr.] 1973, V.O. Becker (VOB); Sector Cerro Cocori, Fca de Elias Rojas, 150 m, (LN 286000-567500), 1 ९ , E. Rojas, Abr 1992, (CRI000786591); A. C. Tortuguero, Sector Cedrales de la Rita, 3 Km Norte, Puente Rio Suerte, Ruta Puerto Lindo, $10 \mathrm{~m}$, (LN 278600-566500), 1 O', E. Rojas, junio 1996, (CRI001149822); R. B. Hitoy Cerere, Valle la Estrella, 100-200 m, (LN 643400-184600), 1 O", G. Carballo, Mar 1994, (CRI001734085); PUNTARENAS: Peninsula de Osa, 50m, 10 " , 12 XI 1972, V.O. Becker, (VOB); Est. Sirena, P. N. Corcovado, 0-100 m, (LS 270500508300), 6 O゙, G. Fonseca, Nov 1989, Jan 1990, Nov 1990, May 1991, Oct 1991, 27 Ago -4 Set 1989, (CRI000113879, CRI000186280, CRI000226344, CRI000563170, CRI000348031, CRI000518538); Bosque Esquinas, A. C. Osa, (LS 302450-345100), 1 ○", 1 ९, M. Segura, May 1994, (CRI001999961, CRI001999949), 1 O", J. F. Quesada, Abr 1993, (CRI001967191); Buen Amigo, San Luis Monteverde, 10001350 m, (LN 250850-449250), 1 o", Z. Fuentes, SET 1994, (CRI002022219); Panama: Barro Colorado Island, 1 \& , 1-9 May 1964, W.D. Duckworth \& S.S. Duckworth, (USNM), (CRI001121338), 1 O", J. Zetek, Oct. 10, 1940, Zetek no. 4683 (USNM)
(CRI001120808), 1 ○゙, J. Zetek, Jul.1, [19]41, (USNM), (CRI001120809), 2 O", 13 Dec., 25? Dec., M. Bates (MCZ).

\section{Euprosterna wemilleri sp. $\mathrm{n}$.}

(Figs. 16, 17, 21, 30, 31)

Adult male (Fig. 30). Forewing length 6.5$7.5 \mathrm{~mm}$. Light brown body. Forewings light brown with dark brown scales scattered over surface forming very evident spots, one at conjunction of veins $M_{2}, M_{1}$ and $C u A 1$, and another over anal veins in submedial area. $R_{3}$ and $R_{4}$ veins stalked off of $R_{2}$. Hindwings light brown like forewings. Labial palps at least $2 \mathrm{X}$ eye length. Legs with light-brown scales; tibial spurs 0-2-2. Antenna bipectinate, short, and curved to median. Haustellum absent.

Adult female (Fig. 31). Forewing length $11 \mathrm{~mm}$. Antennae filiform. Similar to male in patterns and coloration.

Male genitalia (Figs. 16, 17). Uncus with sclerotized downcurved spine at distal end and less sclerotized dorsal process of approx. equal length above. Gnathos slightly upcurved, apex blunt. Valva somewhat sinuous, reaching near apex of uncus, concave and densely setose on inner margin between sacculus and costa. Transtilla with membranous and setose cap above aedeagus. Juxta with small plate below aedeagus and short membranous anellus. Aedeagus twice curved, in short basal end and medially, with basal half at somewhat transverse angle from right to left and $60^{\circ}$ viewed laterally; apex pointed and slightly curved from right to left. Saccus small digitate sclerotized process to posterior.

Female genitalia (Figs. 21). Ductus bursae long, nearly straight from base and curved and wider proximal to corpus bursae; corpus bursae round at base, truncate at distal end with long, narrow signum along distal margin and directed towards base, leaving a cleft in corpus bursae a third distance from the left side. Ostium bursae and antrum narrow, with short sclerotized portion. Ductus seminalis connect to ductus bursae a fifth distance between ostium bursae and corpus bursae. Papillae 

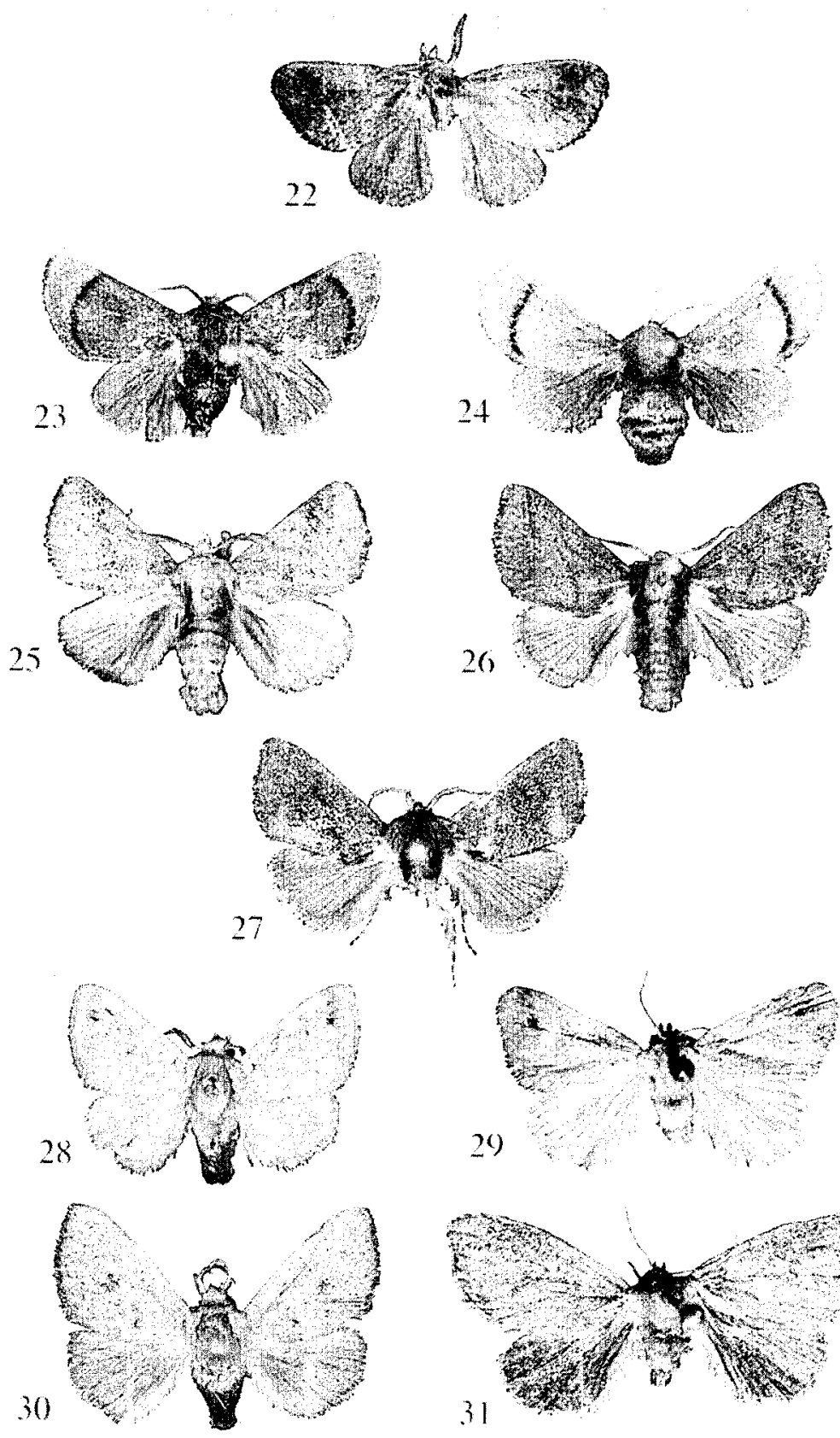

31

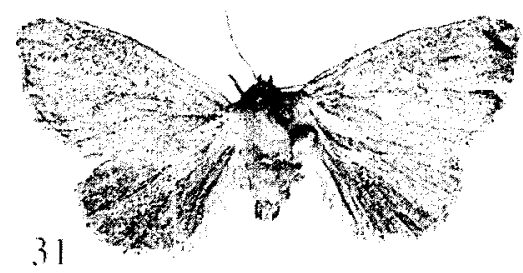

Figures 22-31. Types of new species inthe complex (note" these images are presented at differet scales). 22, Natada minuscula new speces: male (holotype, INBIOCRI001145701); Natada cecilia, new species: 23, male (patatype, CB: INBIOCRI000246169); 24, female (patatype, INBIOCRI001341688); 25, Natada monteverdensis new species: male paratype, INBIOCRI001357909); 26, Natada lalogamezi new species: male (holotype, INBIOCRI1118507); 27, Natada kokii, new species: male (paratype, INBIOCRI001120801); 28-29, Narosopsis iangauldi, new species: 28, male (paratype, INBIOCRI000180626); 29, female (paratype INBIOCRI001999949); 30-31, Euprosterna wemilleri, new species: 30, male (INBIOCRI000242085); 31, female (INBIOCRI0002134099). 
anales convex and rounded along lateral and ventral margin; slightly wider in ventral third; mediodorsal margin nearly vertical to apex. Anterior apophyses short, angled toward dorsum; posterior apophyses curved medially at apex, extending to near anterior margin of 8th segment, narrow and unsclerotized surrounding ostium bursae. Anteroventral portion of 8 th segment sclerotized and smooth.

Remarks: The dorsal process on the uncus of Euprosterna wemilleri appears to be unique in the genus. In undissected specimens, the cucullus has been observed to hook over the dorsal process. E. wemilleri can be easily confused with $E$. hosia Dyar, which has a similar light form with a dark patch on the forewing. Males of $E$. wemilleri can be distinguished by the presence of a large claw on the apex of the uncus and tibial spurs 0-2-2; neither found in $E$. hosia. A unique female specimen described above is either $E$. wemilleri or $E$. hosia. The tibial spur formula (0-2-2) suggests that it is $E$. wemilleri, but the elevation $(700 \mathrm{~m})$ suggests it to be $E$. hosia, since males of this species occur at higher elevations in Costa Rica. Because of this uncertainty, the specimen is not included as a paratype. The second author dedicates this species in honor of his dissertation advisor and mentor, William E. Miller (University of Minnesota), who is a specialist on the systematics of Tortricidae and the biology of Lepidoptera.

Distribution: Known only from Costa Rica. Material examined ( 10 specimens, $90^{\prime \prime}, 1 \%$ )

Holotype O", Costa Rica: LIMON: Cerro Cocori, Finca de E. Rojas, $150 \mathrm{~m}$, (LN 286000-567500), J. F. Corrales, 24 Feb 1994, (CRI001942947).

Paratype. Costa Rica: LIMON: Cerro Cocori, Finca de E. Rojas, 150 m, (LN 286000567500), 2 O’, E. Rojas, Mar 1991, Abr 1991, (CRI000641148, CRI000181572); Est. Cuatro Esquinas, P. N.Tortuguero, 0 m, (LN 280000590500), 20", J. Solano, Oct 1990, (CRI000179571), R. Delgado, Nov 1990, (CRI000244131); Sector Cedrales de la Rita, 3 $\mathrm{Km}$ N. del Puente Rio Suerte, Ruta Puerto
Lindo, $10 \mathrm{~m}$ (LN 278600-566500), 207, E. Rojas, AGO 1995, NOV 1996, (CRI002351815, CRI002493452).

Other specimens. Costa Rica: Guanacaste: Est. Pitilla, 9 km S. Sta Cecilia, 700 m, P. N. Guanacaste (LN 330200-380200), 1 \% , C. Moraga, FEB 1995, (CRI002134099); Limon: Cerro Tortuguero, P. N. Tortuguero, $100 \mathrm{~m}$, (LN 285000-588000), 2 O゙, R. Aguilar \& J. Solano, April 1989, (CRI001102845, CRI001102846).

\section{ACKNOWLEDGMENTS}

The authors extend their gratitude to all of INBio's personnel with special thanks to the parataxonomists who collected the material used for this work. Thanks also to José A. Herrera for his excellent illustrations of genitalia and wings, to Bernardo Espinosa and Annie Lovejoy for their enormous help, to Daniel Janzen for providing voucher specimens and information, as well as constant support, and finally, to Julian P. Donahue (LACM), Martin Honey (BMNH), Vitor O. Becker, James S. Miller (AMNH) and Phil Perkins (MCZ) for loaning specimens.

\section{RESUMEN}

Se describe las siguientes especies nuevas del complejo Natada del Nuevo Mundo: Natada minuscula, Natada cecilia, Natada lalogamezi, Natada kokii, Natada monteverdensis, Narosopsis iangauldi, and Euprosterna wemilleri. Natada minuscula es la especie más pequeña del complejo.

\section{REFERENCES}

Becker, V. O. \& M.E. Epstein, 1995. Limacodidae. In Atlas of Neotropical Lepidoptera (J. B. Heppner editor). Checklist: Part 2. pages 128-133.

Dyar, H.G. 1896. The life-histories of the New York slug caterpillars. 3-6. Journal New York Entomological Society. 4: 167-190, plates 5-9. 
Dyar, H.G.1899a. The life histories of the New York slug caterpillars.-(Conclusion). Journal of the New York Entomological Society, 7: 234 253, plates 6-8.

Dyar, H.G. 1899b. The life-histories of the New York slug caterpillars. 18. Joumal New York Entomological Society. 7: 61-67, plate 1 .

Dyar, H.G. 1935. Limacodidae. In The Macrolepidoptera of the World (A. Seitz editor). The American Bombyces and Sphinges. Vol. 6. pages 11041139.11131136 (1937). 11371256 (1936). (from Heppner 1982).

Epstein, M. E. 1996. Revision and phylogeny of the limacodid group families, with evolutionary studies on slug caterpillars (Lepidoptera: Zygaenoidea). Smithsonian Contributions to Zoology. Number 582. 101 pages, 409 figures.
Epstein, M.E. \& V.O. Becker. 1994. Combinations and synonymies in New World Limacodidae, Megalopygidae, Lasiocampidae and Arctiidae (Lepidoptera). Revista Brasileira Zoologica, 10: 289 319. (1993).

Forbes, W.T.M. 1942. The Lepidoptera of Barro Colorado Island, Panama. No. 2. Bulletin Museum Comparative Zoology, 90: 265-406.

Genty, P., R. Desmier, J.P. Morin, and C.A. Korytkowski. 1978. Les ravaguers du palmier a huile en Amerique Latine. Oleagineux, 33: 325419.

Holloway, J.D. 1986. The Moths of Borneo: Key to Families; Families Cossidae, Metarbelidae, Ratardidae, Dudgeoneidae, Epipyropidae and Limacodidae. The Malayan Nature Joumal, 40: 1-166. 